\title{
The role of oral mifepristone in pre-induction cervical ripening at term
}

\author{
Uma H. Chourasia ${ }^{1 *}$, Mudita Kamlesh Jain², Juzar I. Fidvi ${ }^{3}$
}

\begin{abstract}
${ }^{1}$ Department of Obstetrics and Gynecology, College of Medicine, Jazan University, Saudi Arabia ${ }^{2}$ Department of Obstetrics and Gynecology, RKDF Medical College, Bhopal, Madhya Pradesh, India

${ }^{3}$ Department of Obstetrics and Gynecology, Government Medical College, Nagpur, Maharashtra, India
\end{abstract}

Received: 29 August 2019

Accepted: 30 September 2019

*Correspondence:

Dr. Uma H. Chourasia,

E-mail: drumahchourasia@gmail.com

Copyright: $\odot$ the author(s), publisher and licensee Medip Academy. This is an open-access article distributed under the terms of the Creative Commons Attribution Non-Commercial License, which permits unrestricted non-commercial use, distribution, and reproduction in any medium, provided the original work is properly cited.

\section{ABSTRACT}

Background: Planned induction of labor is an established part of modern obstetrics and is used as a definite form of treatment where continuation of pregnancy would be detrimental to the health of mother or fetus. The objective of this study was to evaluate the effect of mifepristone in pre-induction cervical ripening and labor induction.

Methods: A total of 200 pregnant women at term with Bishop Score 4 or less were selected for this prospective randomized placebo-controlled study. The sample was equally divided into study group to receive $200 \mathrm{mg}$ of mifepristone and control group to receive placebo orally for 2 days. Bishop score was assessed at every 24 hours interval till patient entered in spontaneous labor or 72 hours after 1st dose. Women who did not enter labor spontaneously, labor induction was planned with per vaginal insertion of prostaglandin (PG) E2 analogue, Dinoprostone gel $2.5 \mathrm{mg}$ or PGE1 analogue Tab. Misoprostol $25 \mu \mathrm{g}$.

Results: Ninety-six subjects in the study group and eighty-one in the control achieved successful ripening of cervix and the difference was statistically significant. Sixty-eight of study group and thirty-nine of placebo group entered in spontaneous active labor within 72 hours. Requirement of oxytocin as adjuvant treatment was significantly lower in the study group. Nineteen women of study group and fifteen of control group delivered within 24 hours, and eightyone of study group and sixty-two of placebo delivered in 48 hours. The mean induction delivery interval was $35.53 \pm 13.67$ hours in the study group, whereas it was significantly prolonged in the placebo group $50.49 \pm 20.92$ hours. Eighty-two subjects of study group and seventy-eight of the control group delivered vaginally, the differences were statistically not significant.

Conclusions: Mifepristone was found to be an effective agent for cervical priming prior to labor induction in women at term and significantly reduces the induction delivery interval compared with placebo.

Keywords: Bishop score, Cervical ripening, Labor induction, Mifepristone

\section{INTRODUCTION}

Planned induction of labor is an established part of modern obstetrics and is used as a definite form of treatment where continuation of pregnancy would be detrimental to the health of mother or fetus. ${ }^{1,2}$ Cervical ripening is essential for successful outcome of induction of labor. An unripe cervix decreases the likelihood of vaginal delivery. ${ }^{3}$ In current obstetric practice, prostaglandins are commonly used for cervical ripening prior to labor induction. However, prostaglandins may cause uterine hyper stimulation leading to fetal distress or insufficient cervical ripening. ${ }^{4,5}$ Successful cervical ripening prior to labor induction continues to remain a challenge for obstetricians. Mifepristone (RU486) is a steroid compound that binds to progesterone receptor and inhibits the activity of progesterone. It has potent anti- 
progestogenic, anti-glucocorticoid and weak antiandrogenic actions. ${ }^{6,7}$ It has been shown to increase uterine activity and to mature and dilate the pregnant cervix uteri. It shows synergism with prostaglandins and oxytocin, and significantly decreases their requirement in augmentation of labor. Therefore, it seems reasonable to propose mifepristone as an agent for cervical ripening prior to labor induction. The present study investigated the efficacy of mifepristone in pre-induction cervical ripening in women at term, the induction-delivery interval, the need of oxytocin as an adjuvant therapy and the effect of mifepristone on mode of delivery. ${ }^{8}$

\section{METHODS}

A total of 200 pregnant women scheduled for planned delivery with Bishop Score 4 or less were selected for this prospective randomized placebo-controlled study. The study was conducted from October 2004 to October 2006 at Indira Gandhi Government Medical College and Hospital, Nagpur, India after gaining approval from institutional ethical committee. The inclusion criteria were singleton live pregnancy with cephalic presentation at term (37-42 weeks) determined by first trimester ultrasound scan; patients with no contraindication for vaginal delivery; pre-induction Bishop score 4 or less; intact membrane with reassuring non stress test (NST), and in whom the labor induction was indicated and could be postponed for 48 hours. Patients with parity $>5$, known cases of impaired renal, hepatic or adrenal function and hypersensitivity to prostaglandins or mifepristone were excluded. The selected patients were divided equally between mifepristone and placebo group. Informed written consent was obtained from the patients and Bishop score was assessed by vaginal examination. Subjects were randomly assigned by computer generated number to receive either $200 \mathrm{mg}$ of mifepristone or placebo orally for 2 days (days 1 and 2). Bishop score was assessed at every 24 hours interval till patient entered in spontaneous labor or 72 hours after the 1st dose of the treatment. Patients with Bishop score of 6 or more within 72 hours were hospitalized for artificial rupture of membrane (ARM) and augmentation with oxytocin. For women who did not enter labor spontaneously within 72 hrs after the first dose of mifepristone or placebo, labor induction was done with initial dose of per vaginal Dinoprostone gel (PGE2) $2.5 \mathrm{mg}$ or $25 \mu \mathrm{g}$ of Tab. Misoprostol. The primary efficacy measure of successful cervical ripening was assessed by the change in the Bishop score on day 0 of treatment and at 24 hours intervals for 72 hours. The duration of induction delivery interval, number of patients required oxytocin as adjuvant treatment and the mode of delivery were recorded. Change of Bishop score to 6 or more within 72 hours was considered as successful ripening. Bishop score of 5 or less after 72 hours was considered as failure. Fetal wellbeing was assessed by keeping a kick chart for 24 hours and by cardiotocography on day 0 before treatment, and at each review visit. Continuous fetal heart rate (FHR) monitoring was done during labor. Neonatal outcome measures were Apgar score, need for resuscitative measures beyond routine warming and drying, and number of neonatal intensive care unit admissions (NICU).

\section{Statistical analysis}

Statistical Analysis was done by using SPSS 20.0 software. Chi-square test was used for finding the differences between qualitative or categorical variables. To find the differences between two quantitative variables, the unpaired $t$ test was used and to find the differences between two group proportions, Z-test was applied. $\mathrm{P}$ value $<0.05$ was considered statistically significant.

\section{RESULTS}

Table 1: Improvement in mean Bishop score at 24 hours and 48 hours.

\begin{tabular}{|llll|}
\hline $\begin{array}{l}\text { Time in } \\
\text { hours }\end{array}$ & $\begin{array}{l}\text { Study } \\
\text { group } \\
(\mathbf{n}=100)\end{array}$ & $\begin{array}{l}\text { Control } \\
\text { group } \\
(\mathbf{n}=100)\end{array}$ & P value \\
\hline 0 & $2.18 \pm 1.24$ & $2.07 \pm 1.28$ & $0.5378(\mathrm{NS})^{*}$ \\
\hline 24 & $5.6 \pm 2.10$ & $4.96 \pm 1.70$ & $0.0188(\mathrm{~S})^{*}$ \\
\hline 48 & $7.33 \pm 3.53$ & $5.78 \pm 2.48$ & $0.113^{*}$ \\
\hline
\end{tabular}

*Unpaired t test.

Table 2: Successful ripening of cervix and need of adjuvant treatment with oxytocin.

\begin{tabular}{|llll|}
\hline Time in hours & $\begin{array}{l}\text { Study } \\
\text { group } \\
(\mathbf{n = 1 0 0})\end{array}$ & $\begin{array}{l}\text { Control } \\
\text { group } \\
(\mathbf{n = 1 0 0})\end{array}$ & P value \\
\hline Successful ripening & 96 & 81 & $0.001^{\#}$ \\
\hline $\begin{array}{l}\text { Spontaneous labor } \\
\text { in 72 hours }\end{array}$ & 68 & 39 & $0.0001^{\#}$ \\
\hline $\begin{array}{l}\text { Adjuvant treatment } \\
\text { with oxytocin }\end{array}$ & 51 & 76 & $0.0002 * *$ \\
\hline \begin{tabular}{l} 
\# Chi square test, ** Z test. \\
\hline
\end{tabular}
\end{tabular}

Both the Mifepristone and placebo groups were comparable regarding maternal age, gestational age, parity and indications of induction. The mean Bishop score at the start of induction ( 0 hour) in the study group was $2.18 \pm 1.24$ and in the control group $2.07 \pm 1.28$ $(\mathrm{P}=0.5)$. The mean Bishop score was improved to $5.6 \pm 2.10(\mathrm{P}=0.01)$ at 24 hours and to $7.33 \pm 3.53(\mathrm{P}=0.01)$ at 48 hours in the study group (Table 1$)$. The successful ripening of the cervix was more frequent in the study group (96\%) as compared to control group $(81 \%)$ and the difference was statistically significant $(\mathrm{P}=0.001)$. Sixtyeight patients of study group and thirty-nine of placebo group were entered in spontaneous active labor within 72 hours of observation period. Requirement of oxytocin as adjuvant treatment was significantly lower in the mifepristone group (Table 2). Nineteen women of study group and fifteen of placebo group delivered in 24 hours; 
and eighty-one of study group and sixty-two of placebo group delivered in 48 hours (Table 3 ).

Table 3: Number of patients delivered in 24 and 48 hours.

\begin{tabular}{|llll|} 
Time in hours & $\begin{array}{l}\text { Study } \\
\text { group } \\
(\mathrm{n}=\mathbf{1 0 0})\end{array}$ & $\begin{array}{l}\text { Control } \\
\text { group } \\
(\mathrm{n}=\mathbf{1 0 0})\end{array}$ & P value \\
\hline Delivered in 24 hours & 19 & 15 & $0.45^{* *}$ \\
\hline Delivered in 48 hours & 81 & 62 & $0.001 * *$ \\
\hline$* * \mathrm{Z}$ test.
\end{tabular}

The mean induction delivery interval was $35.53 \pm 13.67$ hours in the study group whereas it was $50.49 \pm 20.92$ hours in the placebo group. Although the number of patients delivered vaginally (82) in the study group were more than the placebo group (78), the difference was non-significant. Similarly, the differences in number of instrumental and cesarean deliveries were non-significant (Table 4). The indications for cesarean sections: fetal distress, failed induction and arrest of labor were comparable in both the groups (Table 5). The neonatal outcome was comparable in both the groups (the Apgar score $<7$ at 1 minute and 5 minutes). Three neonates in the placebo group and one of mifepristone group required NICU admission; the difference was statistically nonsignificant.

Table 4: Induction to delivery interval and mode of delivery.

\begin{tabular}{|llll|}
\hline & Study group $(\mathrm{n}=100)$ & Control group $(\mathrm{n}=100)$ & P value \\
\hline Mean induction delivery interval & $35.53 \pm 13.67$ & $50.49 \pm 20.92$ & $0.0001^{*}$ \\
\hline Mode of delivery & & & \\
\hline Vaginal & 82 & 78 & 05 \\
\hline Instrumental & 03 & 17 & $0.69^{\#}$ \\
\hline LSCS & 15 & & \\
\hline
\end{tabular}

*Unpaired t test; \#Chi square test.

Table 5: Indications of cesarean section.

\begin{tabular}{|c|c|c|c|}
\hline Indications & $\begin{array}{l}\text { Study } \\
\text { group } \\
(n=15)\end{array}$ & $\begin{array}{l}\text { Control } \\
\text { group } \\
(n=17)\end{array}$ & $\begin{array}{l}\mathbf{P} \\
\text { value }\end{array}$ \\
\hline Fetal distress & 8 & 9 & \multirow{3}{*}{$0.962^{\#}$} \\
\hline Failed induction & 4 & 4 & \\
\hline Arrest of labor & 3 & 4 & \\
\hline
\end{tabular}

\section{DISCUSSION}

Mifepristone (RU486) an oral antiprogesterone has recognized role in first and second trimester medical termination of pregnancy. ${ }^{8,9}$ As per the Cochrane database review 2009, there are insufficient clinical trials to support use of Mifepristone in labor induction. ${ }^{10}$ The aim of our study was to evaluate the efficacy of 2 doses of $200 \mathrm{mg}$ mifepristone at 24 hours interval in preinduction cervical ripening at term.

The study demonstrated significant and progressive improvement in Bishop Score at 24 and 48 hours in the study group of 100 patients as compared to control group. Significant number of women $(68 \%)$ entered in spontaneous labor in 72 hours of observation period and shorter mean induction delivery interval $(35.53 \pm 13.67$ hours) was noted in the study group as compared to control (50.49 \pm 20.92 hours). Our results are similar with the findings of Frydman et al, who studied the efficacy of 2 doses of 200 mifepristone in 60 patients at term, Baev et al, studied 74 women at term with 2 doses of $200 \mathrm{mg}$ mifepristone and Giacalone et al, who used single dose of $400 \mathrm{mg}$ of mifepristone in 42 patients with 48 hours of observation period. Wing et al, and Yelikar et al, used $200 \mathrm{mg}$ single dose of mifepristone followed by $25 \mu \mathrm{g}$ of misoprostol for cervical ripening in prolonged pregnancies. ${ }^{11-15}$ Wing et al, observed a modest effect on cervical ripening in 24 hours but the difference was not statistically significant and proposed that longer exposure to mifepristone might be needed to show significant difference in cervical ripening. ${ }^{14}$ Yelikar et al, noted improvement in mean Bishop score at the end of 24 hours and significant reduction in induction delivery interval. ${ }^{15}$ Elliott CL et al, reported successful cervical ripening with a dose of $50 \mathrm{mg}$ mifepristone in $48 \%$ patient and with $200 \mathrm{mg}$ mifepristone in $64 \%$ patients; women entered in spontaneous labor were statistically significant in $200 \mathrm{mg}$ mifepristone group at 72 hours. ${ }^{16}$ They concluded that 50 $\mathrm{mg}$ of Mifepristone failed to reach significant levels of cervical ripening and doses greater than $200 \mathrm{mg}$ could have more pronounced effect. Mc Gill and Shetty reported sufficient cervical ripening with $400 \mathrm{mg}$ of mifepristone with in within 48 hours. Study of Atawale et al and Fathima et al, observed significant improvement in Bishop score with mifepristone administration. ${ }^{17-19}$

Our study demonstrated significant reduction in the need of augmentation with oxytocin in study group (51\%) compared to control group $(76 \%)$, consistent with the findings of Hapangama and Neilson, Wing et al, Athawale et al, and Yelikar et al. ${ }^{14,15,18}$ Although the present study and study of Baev et al, reported nonsignificant difference in the mode of delivery in study 
and control group, studies by Mc Gill and Shetty, Fathima et al, and Athawale et al, observed more vaginal deliveries and significantly less cesarean sections in mifepristone group. ${ }^{12}$ The immediate neonatal outcome was comparable in both the study and control groups in the present study, similar to the findings of Hapangama and Neilson, Fathima et al, Yelikar et al and Baev et al.

\section{CONCLUSION}

Two doses of $200 \mathrm{mg}$ of mifepristone at 24 hours interval in a 72 hours observation period was found to be significantly effective for pre-induction cervical ripening in term patients. It showed marked improvement in the Bishop score within 48 hours. Mifepristone reduces the induction delivery interval and need of augmentation after cervical ripening. It increases the number of patients entering into spontaneous labor without any immediate neonatal complications.

\section{Funding: No funding sources}

Conflict of interest: None declared

Ethical approval: The study was approved by the Institutional Ethics Committee

\section{REFERENCES}

1. Sanchez-Ramos L. Induction of labor. Obstet Gynecol Clin North Am. 2005;32:181-200.

2. Laughon SK, Zhang J, Grewal J, Sundaram R, Beaver J, Reddy UM. Induction of labor in a contemporary obstetric cohort. Am J Obstet Gynecol. 2012;206:486.e1-486.e9.

3. Surita FG de C, Cecatti JG, Kruppa F, Tedesco RP, Parpinelli MÂ. Cervical ripening methods for labor induction. Rev Bras Saúde Materno Infant. 2004;4:125-33.

4. Jackson GM, Sharp HT, Varner MW. Cervical ripening before induction of labor: a randomized trial of prostaglandin E2 gel versus low-dose oxytocin. Am J Obstet Gynecol. 1994;171:1092-6.

5. Srisomboon J, Tongsong T, Tosiri V. Preinduction cervical ripening with intravaginal prostaglandin E1 Methyl analogue Misoprostol: a randomized controlled trial. J Obstet Gynaecol Res. 1996;22:11924.

6. Heikinheimo O. Clinical pharmacokinetics of Mifepristone. Clin Pharmacokinet. 1997;33:7-17.

7. Van Look PF, von Hertzen H. Clinical uses of antiprogestogens. Hum Reprod Update. 1995;1:1934.

8. Kulier R, Kapp N, Gülmezoglu AM, Hofmeyr GJ, Cheng L, Campana A. Medical methods for first trimester abortion. Cochrane Database Syst Rev. 2011;CD002855.

9. Wildschut H, Both MI, Medema S, Thomee E, Wildhagen MF, Kapp N. Medical methods for midtrimester termination of pregnancy. Cochrane Database Syst Rev. 2011. Available at: https://www.cochranelibrary.com/cdsr/doi/10.1002/1 4651858.CD005216.pub2/full.

10. Hapangama D, Neilson JP. Mifepristone for induction of labour. Cochrane Database Syst Rev. 2009; CD002865.

11. Frydman R, Lelaidier C, Baton-Saint-Mleux C, Fernandez H, Vial M, Bourget P. Labor induction in women at term with mifepristone (RU 486): a double-blind, randomized, placebo-controlled study. Obstet Gynecol. 1992;80:972-5.

12. Baev OR, Rumyantseva VP, Tysyachnyu OV, Kozlova OA, Sukhikh GT. Outcomes of mifepristone usage for cervical ripening and induction of labour in full-term pregnancy. Randomized controlled trial. Eur J Obstet Gynecol Reprod Biol. 2017;217:144-9.

13. Giacalone PL, Targosz V, Laffargue F, Boog G, Faure JM. Cervical ripening with mifepristone before labor induction: a randomized study. Obstet Gynecol. 1998;92:487-92.

14. Wing D, Fassett M, Mishell D. Mifepristone for preinduction cervical ripening beyond 41 weeks' gestation: a randomized controlled trial. Obstet Gynecol. 2000;96:543-8.

15. Yelikar K, Deshpande S, Deshpande R, Lone D. Safety and efficacy of oral mifepristone in preinduction cervical ripening and induction of labour in prolonged pregnancy. J Obstet Gynaecol India. 2015;65:221-5.

16. Elliott CL, Brennand JE, Calder AA. The effects of mifepristone on cervical ripening and labor induction in primigravidae. Obstet Gynecol. 1998;92:804-9.

17. McGill J, Shetty A. Mifepristone and misoprostol in the induction of labor at term. Int J Gynaecol Obstet Off Organ Int Fed Gynaecol Obstet. 2007;96:80-4.

18. Athawale R, Acharya N, Samal S, Hariharan C. Effect of mifepristone in cervical ripening for induction of labour. Int J Reprod Contracept Obstet Gynecol. 2016;2:35-8.

19. Nayak SR, Rao B. Mifepristone in the induction of labour at term. Int J Pharm Biomed Res. 2013;4:1646.

Cite this article as: Chourasia UH, Jain MK, Fidvi JI. The role of oral mifepristone in pre-induction cervical ripening at term. Int J Reprod Contracept Obstet Gynecol 2019;8:4337-40. 